\title{
Assessing the factors motivating Agricultural Teachers towards exposing their students to Agricultural Production as Source of Livelihood; Case study of Odeda Local Government Area, Ogun State, Nigeria
}

\author{
Adesokan $\mathrm{FB}^{1 *}$, Odetola $\mathrm{EF}^{2}$, Adediji $\mathrm{OM}^{3}$, Adeniyi $\mathrm{BJ}^{4}$, Faleye $\mathrm{OS}^{5}$. \\ ${ }^{1}$ Forestry Research Institute of Nigeria, Jericho Hill Ibadan Oyo state, ${ }^{2}$ Adekunle Ajasin University, Akungba Akoko, Ondo State \\ Nigeria, ${ }^{3}$ Xian Jiaotong University, China, ${ }^{4,5}$ Federal university of Agriculture, Abeokuta, Ogun State, Nigeria.
}

\begin{abstract}
The importance of agricultural production to Nigeria's economy cannot be overemphasized. Several researchers have proposed various techniques towards quantifying the effects of agricultural production on our economy, but the factors motivating agricultural teachers into exposing young students to the practical aspect of agricultural production has not been discussed. To address this, this research assessed the factors motivating agricultural teachers towards exposing their students to agricultural production as source of livelihood: Case study of Odeda Local Government Area, Ogun State, Nigeria. Data was collected using well-structured questionnaire and interview. The study involved 5 HODs and 25 teachers selected using purposive sampling technique and simple random sampling technique respectively. Data were analysed quantitatively using descriptive statistics, whereas content analysis techniques were used to analyze qualitative data collected using interview schedules. The analyzed data were presented in form of tables, pie-charts and bar-graphs where applicable. At the end of the study, it was revealed that the teaching experience of a high percentage of the respondents ranged between 16-20 years. It was indicated that the respondents were satisfied with their job. A higher percentage of the respondents were involved in agricultural production either subsistence or commercial. It was shown that only a few percentages of the respondents had 6-10 years farming experience. However, among other methods of land acquisition, the land acquisition by inheritance was mostly adopted by the respondents. Most of the respondents were active members of a farmers' association, and they have passion for agricultural production, hence, planned to continue in the practice as a primary source of livelihood after retirement from teaching profession. It was gathered that various factors like supervision, leadership, work environment condition, perceived fairness in promotion system and promotion opportunities elsewhere affects job satisfaction. The study discovered that most of the respondents are into crop farming as a secondary means of livelihood and eighty (80) percent of the teachers are willing to expose their students into agricultural production as a source of livelihood, which will eventually alleviate poverty and reduce the search for white collar jobs in Nigeria.
\end{abstract}

Keywords: Assessing, motivation, exposure, graduate, agricultural, production.

\section{INTRODUCTION}

Agriculture used to be the throttlehold of Nigeria's economy prior to the oil boom. Nigeria was considered a powerhouse in the production of cocoa, palm kernel and other cash crops. For a very long time, this sector of the economy was neglected until recently. The current administration has made some famous efforts to perk up this money spinning sector of the economy and bring it back to its magnificent days, jobs have been and still being created under agricultural sectors, which has been encouraging young graduates to participate, and

*Address of Correspondence: Dr. Adesokan FB. Email address: odetolasenior@gmail.com

(Received 14 September 2020; revised 16 September 2020; accepted 17 September 2020) 
take up agriculture as an option to seeking white collar jobs. According to the Census 2011, every day two thousand $(2,000)$ farmers give up cultivation. The young among the farming communities are hardly interested in agricultural activities. Research has shown that majority of students who graduate from agricultural universities switch over to other professions. Although 80-90 per cent of students studying agriculture belong to the farming community, most of them prefer to choose a different career. At present, around 0.4 million students are enrolled in agricultural universities and institutes. Although despondently, a very small number of about 0.1 million students manage to graduate. Most of them (between 70 and 80 per cent) join the banking sector (1). Students and agricultural teachers of learning institutions like to feel that someone care about their work and appreciate it, which in turn incite them to perform better. Asim, (2013) describes motivation as the services that cause people to perform as they do (2). Agricultural tutors' enticement plays a central role in motivating students into deciding whether to practice agricultural production as a choice of livelihood. Generally, motivated agricultural teachers are more likely to motivate their students to learn effectively and to ensure the implementation of agricultural educational reforms and feelings of satisfaction and fulfilment. According to Chen \& Zheng, (2020), high levels of job discontent, stress, and burnout can negatively influence motivation and job performance(3). Many factors have been found to promote agricultural teachers' motivation. Experienced tutor and pay incentives, for example, have been found to be successful in increasing motivation. Because of this, this research aims at assessing the factors motivating teachers into exposing their students into agricultural production as a means of livelihood. The rest of this paper is organized as follows: Section II examined some existing works in the area of teachers' motivational factors and agricultural production, Section III and IV presents the research methodology and results, Section $\mathbf{V}$ concludes.

\section{LITERATURE REVIEW}

Agricultural Teachers' motivation is an intricate term to define; therefore a specific definition of this concept is elusive as the notion comprises the characteristics of individual and situation and also, the awareness of that situation by the individual. Hargrove, Nelson, \& Cooper, (2013) assert that organization's liveliness comes from the motivation of its employee, although their abilities play just as vital a role in determining their work performance as their motivation (4). Motivated and committed agricultural teachers can be a determining factor in the success of an institution. For a teacher to be motivated job satisfaction must be evident. Job satisfaction in this context is the level of gratification of agricultural teachers with their jobs. Qureshi \& Hamid, (2017) defined job satisfaction as a pleasurable or positive emotional state resulting from the appraisal of one's job or job experiences (5). There are a variety of factors that influence a person's level of job satisfaction. These may comprise of earnings, working condition, equality of promotion structure, social relationships, leadership and the job itself. Job satisfaction or dissatisfaction often affects teachers' relationship with co-workers, students and other administrative staff. Job gratification is one of the main keys to the long-term development of any educational system in Nigeria.

Job satisfaction has been the most frequently investigated variable in organizational behaviour (6). Job satisfaction varies from one individual to another.Mahmood, et al., (2011), suggested that the higher the prestige of the job, the greater the job satisfaction (7). Many workers, however, are satisfied in even the least prestigious jobs; they simply like what they do. Job satisfaction can be influenced by a variety of factors, e.g. the quality of one's relationship with their supervisor, the quality of the physical environment in which they work, and the degree of fulfilment in their work. On the other hand, improved job satisfaction can sometimes decrease job performance. Jobs are different in the extent to which they approach five core dimensions: skill assortment, task uniqueness, task significance, autonomy, and task feedback (7). If jobs are designed in a way that increases the presence of these core characteristics, three critical psychological states can occur in employees: experienced meaningfulness of effort, 
experienced responsibility for labour outcomes and knowledge of the results of work activities (7). There are three models in relation to job satisfaction. These are situational, dispositional, and interactional models. These three main lines of models have been used extensively to predict the job satisfaction of employees in organizations. The interactional model of job satisfaction argues that the fit between the person and the environment influences job satisfaction. This approach is known as the Person-Environment Fit. A study done by Mamatha \& Prasad, (2018) on factors related to the morale of Agriculture Teachers found that the factors affecting teachers morale includes: dissatisfaction with school authorities, low earnings and constant scarcity, late payment, poor career structure, unfair promotion opportunities, poor school facilities, inadequate school disciplinary policy, attitudes and behaviour of the school head and of other teachers, and pupil's pitiable effort attitudes and lack of concentration in education (8).

Teacher Reward Systems such as Remuneration and Compensation: Rewarding employees is an important factor in employee motivation. Majority of schools have achieved immense progress by fully complying with their teaching strategy through a well-structured compensation and recognition programs for the workers in their respective schools. Drive of employees and their output can be enhanced through the provision of effective recognition which ultimately results in improved performance of organizations. The entire success of schools is based on how a school keeps its workers motivated and in what way they evaluate the performance of employees for job compensation. At times management pays more attention to extrinsic rewards but intrinsic rewards are equally important in employee motivation. Rewards like positive receptions and acknowledgment plays a crucial role in appealing the teachers and increasing their performance. Safiullah, (2014) concludes that commitment of employees is based on rewards and recognition (9). Danish \&Usman (2010) argued that prosperity and survival of the organizations is determined through how they treat their human resource (10). In retention, linking pay to performance is likely to help improve workforce composition (9). High performers tend to gain a larger share of compensation resources and thus are motivated to stay with the organization. Below to average performers becomes discouraged and tend to leave the organization. Thus the effect of motivation on the performance and retention of employees should be assessed and addressed in public organizations. If employees feel that their inputs outweigh the outputs then they become de-motivated in relation to the job and the employer. Employees respond to this feeling in different ways, as the extent of de-motivation is proportional to the perceived disparity between inputs and expected outputs. Some employees reduce effort and application and become inwardly disgruntled, or outwardly difficult or even disruptive. Other employees seek to improve the outputs by making the claims or demands for more rewards, seeking an alternative job. The importance of this theory is to realize that perceptions of equitable treatment generate motivational forces that investigate behaviour to reduce the tension and that quite often a variety of behaviours are available for correcting a situation of perceived inequality. Safiullah, (2014) advocates that there should be an effective reward system to retain the high performers in the organization and reward should be related to their productivity (9). In order to maximize the performance of the teachers, institutions must mandate such policies and measures and create a reward system under those measures which increase contentment and enthusiasm. Asim, (2013) suggested that pay is directly related with productivity and reward system depends upon the size of an organization (2). Recently, competitive situations want to decide the reasonable stability between workers' loyalty and commitment, and performance of the organization. Well-organized remuneration system can be a good instigator while inefficient remuneration system can cause loss of motivation among the employees. The fact is that low wages drive teachers into other activities to the detriment of teaching. Mahmood et al., (2011) identified low salaries as the most harmful factor for the education sector in general (7). 
Work Situation Factors also affects Teachers' motivation. According to Muttie ur et al., ( 2012) research studies across many years, organizations, and types of jobs show that when employees are asked to evaluate different facets of their profession such as compensation, administration, promotion opportunities, and so forth. The character of the work itself generally emerges as the most important job facet (6). However, this does not imply that good compensation programs are insignificant; but, it means a lot can still be done to manipulate job contentment by making sure work is as interesting and challenging as possible. Despondently, some administrators think workers are most eager of pay to the omission of other job aspects. For example, according to McKim, Sorenson, Velez, \& Henderson, (2017)in a study examining the importance of job attributes, employees ranked interesting work as the most important job attribute and good earnings were fifth, while, good wages ranked first (11). According to Mahmood et al., (2011), of all the major job satisfaction areas, satisfaction with the nature of the work itself which includes job challenge, autonomy, variety, and scope best envisage general job contentment, and other important results like employee retention (7). To have an in-depth knowledge of what causes workers to be pleased with their career, the scenery of the work itself is one of the first places for practitioners to focus on.

Work Environment and Teacher Motivation; the work environment has a significant impact upon employee performance and productivity. However, work surrounding implies the construction and conditions in the work establishment that impact favourable $o$ good or harsh performance of the workers. Environment also comprises the procedure, customs, funds, rules work relationships, work location and internal and external environmental factors, all of which influence the ways those employees perform their job functions. According to Abu-Shamaa, et al., (2015), environment in which people work affects both job performance and job satisfaction (12). However tasks labour carry out modernized buildings are progressively more and depend on classy technology; and corporation whose residence costs are escalating generally seek to reduce them lacking adversely affecting the workers. Such resolution aim to generate an outlay in employees 'excellence of life, the argument being made that measurable productivity increases will result. Mupanemunda (2020), adds that, researchers are increasingly finding links between employee health and aspects of the physical environment at work such as indoor air quality and lighting (13). Existing narrative on trauma in the effort setting classically aimed on psychosocial factors that shape job presentation, strain and employee wellbeing. Some speculative models of stress at work have highlighted physical environment as the main cause. But in some cases, studies referring to physical environment factors tend to refer to the physical parameters of the tasks being performed rather than to features of the physical space in which work is done. According to Oliver, (2019), it is important for management's effort to create a working environment where everyone is highly motivated and feels valued (14). He adds that if staff look after their health, they will be better in their own lives and in the business.

Preparation of the space and Teacher Motivation; whereas size measures the amount of space per employee, arrangement refers to the distance between people and facilities. Giang and Nguyen, (2017) says that the arrangement of one's workspace is important primarily because it significantly influences social interaction (15). An employee's work location therefore is likely to influence the information to which one is privy and one's inclusion or exclusion from organization's events. Whether you are on a certain grapevine network or not, for instance, will be largely determined by where you are physically located in the organization. According to Dwiandr (2013), one topic that has received a considerable amount of attention is furniture arrangements in traditional offices (16). Unlike factory floors, individuals typically have some leeway in laying out their office furniture. For instance, a desk between two parties conveys formality and authority of the officeholder, while setting chairs, so individuals can sit at right angles to each other conveys a more natural and informal relationship. Privacy within the work place is in 
part a function of the amount of space per person and the arrangement of that space. But walls, partitions and other physical barriers also influence it. One of the most widespread work space design trends in recent years has been the phasing out of closed offices and replacing them with open office plans that have a few, if any walls or doors. Bakr, El Sayad, \& Thomas (2018) said that sometimes described as the cave versus cube debate, the former provides privacy whereas the latter facilitates open communication (17).Caves limit interaction and thus organizations have sought to increase flexibility and employee collaboration by removing physical barriers like high walls, closed offices and doors. According to Acquisti, Taylor and Wagman, (2016), there is also growing evidence that the desire for privacy is a strong one on the part of many people, yet the trend is clearly toward less privacy at the work place (18). Further research is needed to determine whether organizational efforts to open workspaces and individual preferences for privacy, are incompatible and results in lower employee performance and satisfaction. However, a conducive and pleasant setting is as well an essential element in teachers' motivation. There are also growing evidence that the desire for privacy is a strong one on the part of many people, yet the trend is clearly towards less privacy at the work place Acquisti et al., (2016). Facilities in mostschools are dilapidated and inadequate (18). Onyemuche, (2018) recommended that greater attention should be given to improving work-related conditions of teachers to improve the quality of education (19). Specifically, there should be modernized and advances in the provisions of coaching, learning resources, and general classroom atmosphere to mend student learning. Okenwa and Igbo, (2013) argues that if people work in a clean, friendly environment they will find it easier to come to work (20). However, if opposing, coaching and learning will not be imparted as prerequisite, functioning situations are prospective to have a minor impact on job satisfaction when, for example, the working conditions are either extremely good or extremely poor. Additionally, when workers criticize working environments, such issues are frequently related to indexes of underlying problems. Teachers' workload, changes in the education system and a lack of discipline amongst some of the learners may be some of the reasons why teachers want to exit the profession. According to Adamu B, (2019), the working environment of teachers also determines the attitude and behaviour of teachers towards their work (21). He indicates that research has shown that improvement in teacher motivation has a positive effect on both teachers and learners.

Summary of the literature review, the researcher reviewed different literature pertaining to the factors influencing teacher incitement. On the effect of job satisfaction on teacher incitement, it was found that income; perceived fairness of promotion system, quality of working condition, social relationships, leadership and the job itself affect job satisfaction among employees. Regarding the effect of reward system on teacher motivation, it was found that appreciation from the boss, pay, bonuses, fringe benefits, and promotions affect teacher motivation. It was also found that teacher training and development affects their incitement as training is found to be correlated with productivity and retention. Organizations with extensive training opportunities should experience lower turnover rates. On the work situational factors, it was found that work place arrangement and availability of teaching and learning resources affect teachers 'incitement. This study is therefore aimed at assessing the incitement factors affecting teacher's performance in education delivery in public schools of Odeda Local Government Area.

\section{METHODOLOGY The study (research) area}

The study was conducted in Odeda Local Government area of Ogun state Nigeria. This is one of the local governments and towns in Ogun state Nigeria. The local government covers an area of 1,560. $\mathrm{Km}^{2}$ and a population of 109,449 at the 2006 census. The economic activities of the people living in Odeda include mainly farming in the rural areas and trading in the urban areas. This study was carried out in public schools in Odeda Local Government area of Ogun State. 


\section{Data collected and sampling techniques}

Primary relevant data were used, using a wellstructured questionnaire \interview. The questionnaire are targeted toward the Agricultural teachers and HODs i.e. head of department, Purposive sampling technique was used to sample HODs while simple random sampling technique was used to sample teachers. The main advantage of simple random sampling technique is that it gave equal chances for the teachers to be sampled for the study. On the other hand, purposive sampling technique was deemed appropriate for the study as it allowed only those who were perceived to have specific information required for the study. Out of the many schools in the Local Government, 5 were used for the study. A total of 30 respondents were targeted by the study.

\section{Data Analysis \\ Analytical technique includes}

Primary data were collected through a wellstructured questionnaire from the study area, and were critically analyzed using descriptive statistics while content analysis techniques were used to analyze qualitative data collected using interview schedules. Descriptive statistics such as frequencies and percentages were used to describe the data. The analyzed data were presented in form of tables, pie-charts and bargraphs where applicable.

\section{RESULTS}

The teachers in the study area are majorly male making up to $63.3 \%$ while the remaining $36.7 \%$ are female. This shows that the majority of the agricultural teachers are male. This is because male and female are considered in the study, as shown in Table 1.

Table 1: Showing Sex distribution of the respondent

\begin{tabular}{ccc}
\hline Gender & Frequency & Percentage \\
\hline Male & 19 & 63.3 \\
Female & 11 & 36.7 \\
Total & 30 & 100 \\
\hline
\end{tabular}

Distribution of respondent by Highest Academic Qualifications

It turned out that $12(40 \%)$ of the respondents had NCE Degree. The study also found that 10 $(33.3 \%)$ had Bachelor Degree in education and that $8(26.7 \%)$ had Master degree. From the findings of the study, it can be said that agricultural teachers in public schools in Odeda Local Government were qualified agricultural teachers. This is shown in Table 2.

Table 2: Showing academic qualifications

\begin{tabular}{ccc}
\hline Academic qualification & Frequency & Percentage \\
\hline NCE & 12 & 40 \\
BSc & 10 & 33.3 \\
MSc & 8 & 26.7 \\
\hline
\end{tabular}

\section{Distribution of the respondent by their age bracket}

The findings shows that $6(20 \%)$ of the teachers interviewed were between 46-55 years, 11 (36.7\%) were between 36-45 years, 4 (13.3\%) were above 55 years, $7(23.4 \%)$ were between
26-35 years and 2 (6.7\%) were between 18-25 years. This means that there are relatively few experienced teachers who can serve as mentors and provide professional support and leadership thus motivating teachers. This is shown in Table 3 below. 
Table 3: Showing distribution of age bracket

\begin{tabular}{ccc}
\hline Age bracket & Frequency & Percentage \\
\hline 18-25years & 2 & 6.7 \\
26-35years & 7 & 23.3 \\
36-45years & 11 & 36.7 \\
$46-55 y e a r s$ & 6 & 20 \\
above 55 & 4 & 13.3 \\
Total & 30 & 100 \\
\hline
\end{tabular}

\section{Distribution of respondent by} teaching experience

As shown in Table 4, 7 (23.3\%) of the respondents indicated that they had taught for a period between $11-15$ years, 7 (23.3\%) of the respondents had taught for a period between 610 years, $9(30 \%)$ had taught for a period between $16-20$ years, 4 (13\%) had taught for a period of above 20 years and that $3(10 \%)$ had taught for a period between 2-5 years. From the result of the study, it can be said that majority of agricultural teachers interviewed had taught for a long period of time, they may not be dissatisfied with their jobs due to stress but by other factors which was the interest of this study. This is depicted in Figure 1.

Table 4: Showing their years of teaching experiences

\begin{tabular}{ccc}
\hline Age bracket & Frequency & Percentage \\
\hline 2 -5years & 3 & 10 \\
6-10years & 7 & 23.3 \\
$11-15 y e a r s$ & 7 & 23.3 \\
$16-20 y e a r s$ & 9 & 30 \\
20above & 4 & 13 \\
Total & 30 & 100 \\
\hline
\end{tabular}

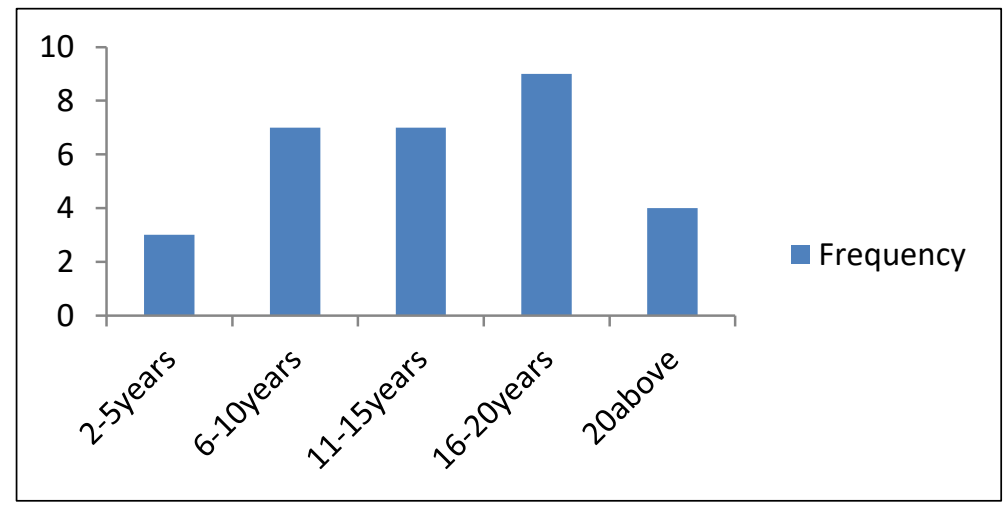

Figure 1: Distribution of respondent years of teaching experiences

\section{Distribution of respondents by Job Satisfaction}

Those who indicated that they were contented with their jobs mentioned the following reasons: That they like teaching agriculture, that they were trained to teach and therefore they were satisfied with the line of work, that it was where they were earning their living and that teaching profession gave them time to do other things. Those who indicated that they were not satisfied mention that they were not getting the results they were expecting out of their effort. The 
findings of the study showed that $30 \%$ are not satisfied with their jobs, while $70 \%$ of the respondents are satisfied. This is depicted in Figure 2.

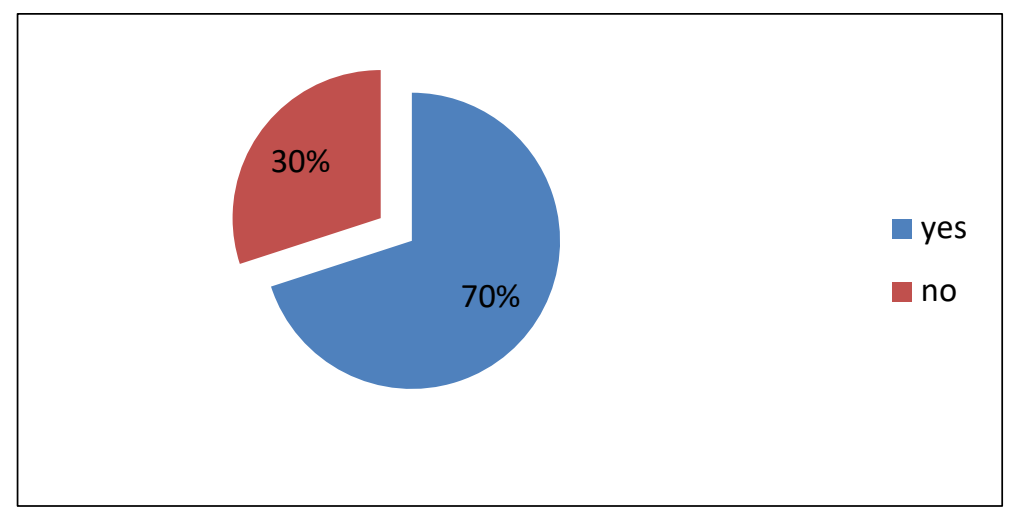

Figure 2: Showing level of job satisfaction

Distribution of respondent showing their involvement in agricultural production

The percentage of the distribution of the respondent show that $87 \%$ of the agricultural teachers are into agricultural production, either subsistence or commercial farming and $13 \%$ are not practically practicing it, this result shows that the teacher are fully practising what they are teaching their student. This is presented in Figure 3.

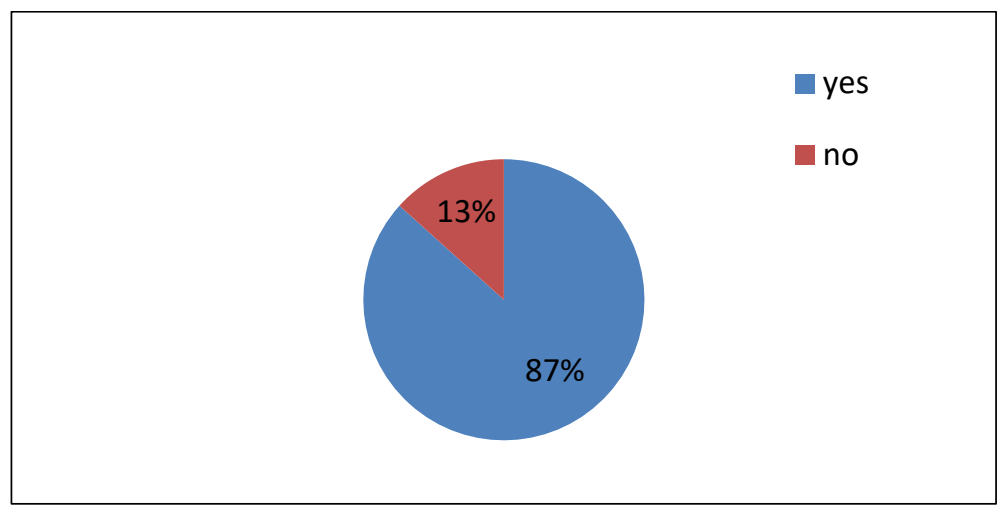

Figure 3: Level of Respondents' Involvement in Agricultural Production

\section{Distribution showing farming experience of the respondent}

Table 5, shows the percentage of the respondents according to their farming experience. The table showed that $10 \%$ of the respondent had the farming experience of 6 10years; $10 \%$ had farming experience of 11 - 15years: $23.3 \%$ had 16-20years of farming experience had $16.7 \%$ and 20years and above had $50 \%$ farming experience. This revealed that majority of the respondent have a level of farming experience which makes them good practical agricultural teachers.

Table 5: Showing their farming year experiences

\begin{tabular}{ccc}
\hline Farming experience(years) & Frequency & Percentage \\
\hline $6-10$ & 3 & 10 \\
$11-15$ & 7 & 23.3 \\
$16-20$ & 5 & 16.7 \\
20 above & 15 & 50 \\
\hline
\end{tabular}




\section{Distribution of respondent showing their secondary choice of livelihood}

Table 6 shows that the percentage distribution of respondents according to their choices of livelihood is shown that $43.3 \%$ of the respondents chose crop production as their secondary source of livelihood, $13.3 \%$ chose non-farm, while $23.3 \%$ and $16.7 \%$ of the respondents chose livestock production and agro forestry livelihood respectively. This is clear evidence that the respondents had secondary source of livelihood as show below.

Table 6: Distribution of respondent based on their secondary choice of livelihood

\begin{tabular}{ccc}
\hline Livelihood choices & Frequency & Percentage \\
\hline crop farming & 13 & 43.3 \\
livestock farming & 7 & 23.3 \\
Agro forestry & 5 & 16.7 \\
Non-farming & 4 & 13.3 \\
\hline
\end{tabular}

Table 7: Method of land acquisition

\begin{tabular}{ccc}
\hline Land Acquisition & Frequency & Percentage \\
\hline Inheritance & 10 & 33.3 \\
Purchase & 5 & 16.7 \\
Leased & 5 & 16.7 \\
Gift & 3 & 10 \\
Community land & 7 & 23.3 \\
\hline
\end{tabular}

\section{Distribution showing the respondent method of land acquisition}

Table 7 reveals that $33.3 \%$ of the respondent acquired their land through inheritance; $16.7 \%$ purchased their farm land $16.7 \%$ leased theirs, and $23.3 \%$ got theirs from the community leaders. Just $10 \%$ got their land as a gift.

\section{Distribution of respondent showing if they belong to any farmer's association}

The percentage distribution of respondents according to their involvement in farmers association is shows that $90 \%$ of the respondents are active member of farmers association while $10 \%$ of the respondents are not found in any farmer association, thus the respondent actively in farm practice. This is depicted in Figure 4.

\section{Distribution of respondents by their zeal to practice Agriculture after Retirement}

The study found out that the respondents have passion for agricultural production. In the findings, $90 \%$ of the respondents planned to continue agriculture as their primary source of livelihood immediately after their retirement from teaching profession while $10 \%$ of the respondent decline going into agriculture base on their personal reasons, hence they are in good stead to expose their students to agricultural production. This is shown in Figure 5 . 


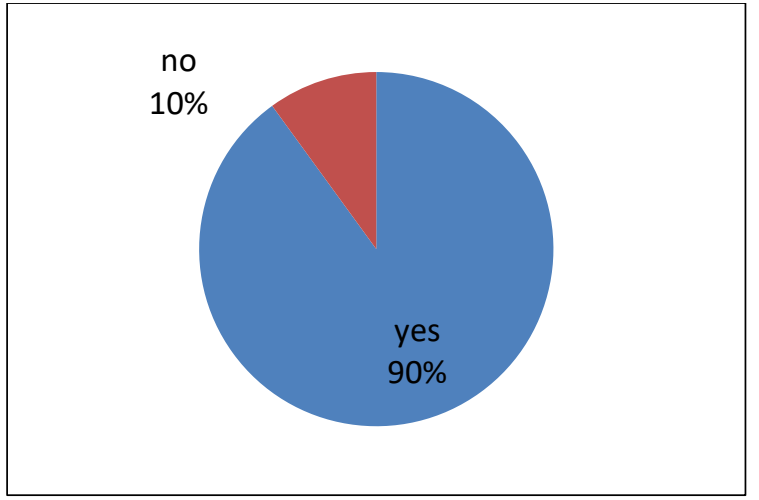

Figure 4: Showing the respondent attachment zeal for agricultural continuality

\section{Distribution of respondent showing factor affecting their job satisfaction}

Table 8 shows that $30 \%$ of the respondents indicated that leadership and the job itself influence job satisfaction. The study also found that $26.7 \%$ of the respondents indicated that perceived fairness in teacher promotion system influence job satisfaction to a small extent. It was found that promotional opportunity elsewhere influences job satisfaction to a very large extent as indicated by $40 \%$ of the respondents. On work environment/condition, the study found that $36.7 \%$ of the respondents indicated that it influences job satisfaction among teachers to a large extent. The study finally found that $36.7 \%$ of the respondents indicated supervision practices do not influence job satisfaction among teachers at all. From the

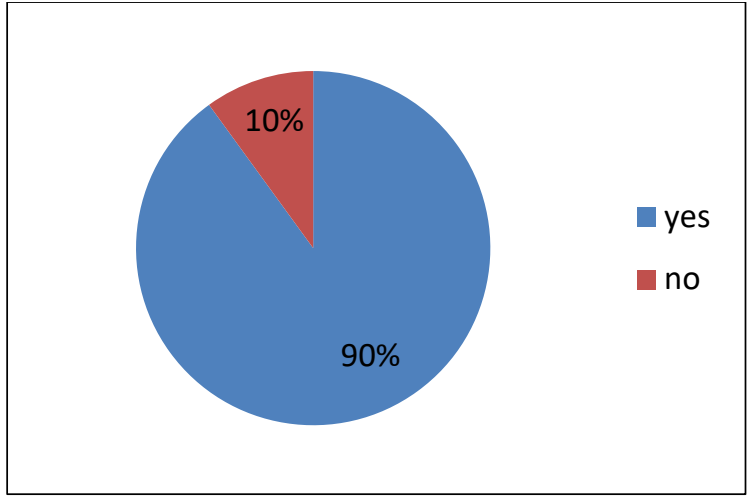

Figure 5: Percentage of respondent showing the in farmers associations

findings of the study, it can be said that leadership style, fairness in promotion opportunities, availability of promotion opportunities, work environment and supervision practices influences job satisfaction among teachers.

\section{Distribution of respondent based on satisfaction with current pay}

Table 9 shows that $19(60.3 \%)$ of the respondents indicated that they were not satisfied with their current pay while 11 $(36.7 \%)$ indicated that they were satisfied with their current pay From the findings of the study, it can be said that the reward system affects teacher incitement in public schools in Odeda Local Government Area.

Table 8: Showing factors affecting job satisfaction

\begin{tabular}{|c|c|c|c|c|c|c|c|c|c|c|c|c|}
\hline \multirow[t]{2}{*}{ statement } & \multicolumn{2}{|c|}{$\begin{array}{c}\text { very large } \\
\text { extent }\end{array}$} & \multicolumn{2}{|c|}{$\begin{array}{l}\text { large } \\
\text { extent }\end{array}$} & \multicolumn{2}{|c|}{ Neutral } & \multicolumn{2}{|c|}{$\begin{array}{l}\text { Small } \\
\text { extent }\end{array}$} & \multicolumn{2}{|c|}{$\begin{array}{c}\text { No extent at } \\
\text { all }\end{array}$} & \multicolumn{2}{|c|}{$\begin{array}{l}\text { Total } \\
(\%)\end{array}$} \\
\hline & $\mathrm{F}$ & $\%$ & $\mathrm{~F}$ & $\%$ & $\mathrm{~F}$ & $\%$ & $\mathrm{~F}$ & $\%$ & $\mathrm{~F}$ & $\%$ & $\mathrm{~F}$ & $\%$ \\
\hline Supervision & 3 & 10 & 3 & 10 & 5 & 16.7 & 8 & 26.7 & 11 & 36.7 & 30 & 100 \\
\hline Leadership and job itself & 9 & 30 & 5 & 16.7 & 4 & 13.3 & 7 & 23.3 & 5 & 15.7 & 30 & 100 \\
\hline Work environment condition & 6 & 20 & 11 & 36.7 & 3 & 10 & 6 & 20 & 4 & 20 & 30 & 100 \\
\hline $\begin{array}{l}\text { Perceived fairness in teachers } \\
\text { Promotion system }\end{array}$ & 7 & 23.3 & 10 & 33.3 & 2 & 6.7 & 8 & 26.7 & 3 & 10 & 30 & 100 \\
\hline Promotional opportunity elsewhere. & 12 & 40 & 8 & 26.7 & 3 & 10 & 4 & 13.3 & 3 & 10 & 30 & 100 \\
\hline
\end{tabular}

Table 9: Showing the response of the respondent with their current pay

\begin{tabular}{ccc}
\hline Response & Frequency & Percentage \\
\hline Yes & 11 & 36.7 \\
No & 19 & 60.3 \\
\hline
\end{tabular}


Distribution of Respondents based on reward system on agricultural teachers incitement The findings on Table 10 shows that 13 (43.3\%) of the respondents strongly disagreed with the statement that the pay given to teachers is worth the services they render. The study also found that $11(37 \%)$ of the respondents strongly disagreed that hardworking teachers are encouraged by giving them presents. It was further found that $12(40 \%)$ of the respondents strongly agreed with the statement that teachers are promoted on the basis of their qualifications and performance. From the findings of the study, it can be said that teacher reward systems affects their incitement. From these findings, it can be concluded that reward systems affect teacher incitement. The respondents were asked to mention other factors affecting job satisfaction among teachers. They mentioned that those who teach academically poor students are never rewarded and that there wards are based on the performance of students in National examinations and therefore those whose students do not pass their examinations are not rewarded thus they are less motivated.

Table 10: Showing the effect of reward system on agricultural teachers incitement

\begin{tabular}{|c|c|c|c|c|c|c|c|c|c|c|c|c|}
\hline \multirow[t]{2}{*}{ Statement } & \multicolumn{3}{|c|}{$\begin{array}{l}\text { Strongly } \\
\text { agree }\end{array}$} & Agree & \multicolumn{2}{|c|}{$\begin{array}{l}\text { Neither } \\
\text { agree or } \\
\text { disagree }\end{array}$} & \multicolumn{2}{|c|}{$\begin{array}{c}\text { Disagr } \\
\text { ee }\end{array}$} & \multicolumn{2}{|c|}{$\begin{array}{l}\text { Strongly } \\
\text { disagree }\end{array}$} & \multicolumn{2}{|c|}{ Total } \\
\hline & $\mathrm{F}$ & $\%$ & $\mathrm{~F}$ & $\%$ & $\mathrm{~F}$ & $\%$ & $\mathrm{~F}$ & $\%$ & $\mathrm{~F}$ & $\%$ & $\mathrm{~F}$ & $\%$ \\
\hline $\begin{array}{l}\text { Diligent agricultural teachers are motivated } \\
\text { by given them prize }\end{array}$ & 2 & 7 & 3 & 10 & 6 & 20 & 8 & 26.7 & 11 & 37 & 30 & 100 \\
\hline $\begin{array}{l}\text { Agricultural teachers are promoted on the } \\
\text { basis of their qualification and performances }\end{array}$ & 12 & 40 & 7 & 23.3 & 1 & 3.3 & 6 & 20 & 4 & 13.3 & 30 & 100 \\
\hline $\begin{array}{l}\text { The pay given to teachers is worth the service } \\
\text { they render(teacher salary) }\end{array}$ & 3 & 10 & 3 & 10 & 2 & 6.7 & 9 & 30 & 13 & 43.3 & 30 & 100 \\
\hline
\end{tabular}

Table 11: Showing in-services attendance

\begin{tabular}{ccc}
\hline Effect of training on teachers incitement & Frequency & Percentage \\
\hline Yes & 23 & 76.7 \\
No & 7 & 23.3 \\
\hline
\end{tabular}

\section{Distribution of Respondents based on Attendance of in-service Training}

The study establish that $23(76.7 \%)$ of the respondents indicated that they had attended in-service training organized for teachers while $7(23.3 \%)$ indicated that they had not attended such trainings. From the findings of the study, it can be said that most of the teachers in public schools in Odeda Local Government had attended trainings organized for teachers. This is shown in Table 11

\section{Distribution of respondent showing the effect of trainings}

Table 12 shows that 11 (36.7\%) of the respondents strongly agreed with the statement that training improves teachers 'confidence thus improving their performance in terms of curriculum delivery. The study also found that $10(33.3 \%)$ of the respondents strongly agreed with the statement that fully trained teachers are ever motivated to teach thus improving their performance in terms of curriculum delivery. The study further found that $13(43.3 \%)$ of the respondents strongly agreed that training among teachers improves their job satisfaction thus improving their performance. The study finally found that 11 (36.7\%) of the respondents agreed that the availability of training opportunities among teachers motivates them to perform. From the findings of the study, it can be said that agricultural teacher training in public schools in Odeda Local Government affect their incitement. The respondents were further asked to mention other ways by which training 
Table 12: Showing the Effect of Trainings

\begin{tabular}{|c|c|c|c|c|c|c|c|c|c|c|c|c|}
\hline \multirow[t]{2}{*}{ Statement } & \multicolumn{2}{|c|}{$\begin{array}{l}\text { Strongly } \\
\text { agree }\end{array}$} & \multicolumn{2}{|c|}{ Agree } & \multicolumn{2}{|c|}{$\begin{array}{l}\text { Neither } \\
\text { agree or } \\
\text { disagree }\end{array}$} & \multicolumn{2}{|c|}{$\begin{array}{l}\text { Disagr } \\
\text { ee }\end{array}$} & \multicolumn{2}{|c|}{$\begin{array}{l}\text { Strongly } \\
\text { disagree }\end{array}$} & \multicolumn{2}{|c|}{ Total } \\
\hline & $\mathrm{F}$ & $\%$ & $\mathrm{~F}$ & $\%$ & $\mathrm{~F}$ & $\%$ & $\mathrm{~F}$ & $\%$ & $\mathrm{~F}$ & $\%$ & $\mathrm{~F}$ & $\%$ \\
\hline $\begin{array}{l}\text { Training among agricultural teachers } \\
\text { improves their job satisfaction thus } \\
\text { improving performance }\end{array}$ & 13 & 43.3 & 6 & 20 & 2 & 6.7 & 3 & 10 & 4 & 13.3 & 30 & 100 \\
\hline $\begin{array}{l}\text { Training improves agricultural teachers } \\
\text { confidences thus improving their } \\
\text { performance in term of curriculum } \\
\text { delivery }\end{array}$ & 11 & 36.7 & 9 & 30 & 3 & 10 & 4 & 13.3 & 3 & 10 & 30 & 100 \\
\hline $\begin{array}{l}\text { Trained teachers are ever motivated to } \\
\text { each other , thus improving their } \\
\text { performance in term of curriculum } \\
\text { delivery }\end{array}$ & 10 & 33.3 & 8 & 26.7 & 4 & 13.3 & 5 & 16.7 & 3 & 10 & 30 & 100 \\
\hline $\begin{array}{l}\text { Availability of training opportunities } \\
\text { among teacher motivate them to perform }\end{array}$ & 11 & 36.7 & 7 & 23.3 & 2 & 6.7 & 6 & 20 & 4 & 13.3 & 30 & 100 \\
\hline
\end{tabular}

\section{Agricultural in-services Training Attendance}

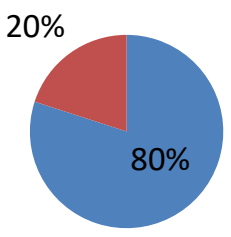

Figure 6: Showing Environmental Satisfaction

affects teacher incitement. The following were mentioned: that the trainings sharpens their teaching skills thus motivating them to teach better, that they learn new methods of teaching aimed at ensuring full understanding of the respondents and that attending teacher trainings allows them to be given promotion. In an interview with the HODs on how reward system affect teacher incitement, they mentioned that good reward systems make teachers to feel satisfied and realize that their work is appreciated.

\section{Distribution of the respondent showing level} of satisfaction with the environment

$80 \%$ respondent indicated that they were satisfied with the school environment mentioned that there were adequate facilities and resources for teaching and learning, that the school is convenient, that the school environment is peaceful and conducive for leaning and that the leadership of the school has created a conducive environment for teachers and the staff working within the school thus motivating them to perform their duties to their abilities, and 20\% indicated that the environment was not conducive mentioned that sometimes their opinions are disregarded and decisions are made to suit school leadership as opposed to those who are being led and that some leaders are over strict thus creating an environment which de-motivates teachers (Figure 6).

Findings on Table 13 shows that $36.7 \%$ of the respondents strongly agreed that teaching and learning resources are inadequate in school thus de-motivating teachers to teach. The study also found that $16.7 \%$ of the respondents strongly disagreed that there are tight rules and regulations in schools which de-motivate teachers. It was also found $36.7 \%$ of the 
respondents strongly disagreed that education policies in schools are tight on teachers thus they get dissatisfied with their jobs. It was finally found that $30 \%$ of the respondents indicated that the arrangement of offices and the spaces available in the offices de-motivates teachers. According to Acquisti (2016), the arrangement of one's workspace is important primarily because it significantly influences social interaction (18).

In an interview with the HOD on the effect of work environment on teacher incitement, they mentioned that favourable working environment motivates teachers thus making them willing to stay longer at their work places thus increasing their contact hours with the students.

Table 13: Showing the effect of environment on agricultural teachers incitement

\begin{tabular}{|c|c|c|c|c|c|c|c|c|c|c|c|c|}
\hline \multirow[t]{2}{*}{ Statement } & \multicolumn{2}{|c|}{$\begin{array}{l}\text { Strongly } \\
\text { agree }\end{array}$} & \multicolumn{2}{|c|}{ Agree } & \multicolumn{2}{|c|}{$\begin{array}{l}\text { Neither } \\
\text { agree or } \\
\text { disagree }\end{array}$} & \multicolumn{2}{|c|}{$\begin{array}{l}\text { Disagre } \\
\mathrm{e}\end{array}$} & \multicolumn{2}{|c|}{$\begin{array}{l}\text { Strongly } \\
\text { disagree }\end{array}$} & \multicolumn{2}{|c|}{ Total } \\
\hline & $\mathrm{F}$ & $\%$ & $\mathrm{~F}$ & $\%$ & $\mathrm{~F}$ & $\%$ & $\mathrm{~F}$ & $\%$ & $\mathrm{~F}$ & $\%$ & $\mathrm{~F}$ & $\%$ \\
\hline $\begin{array}{l}\text { The arrangement of teacher and the space } \\
\text { available in the office De-motivate } \\
\text { agricultural teachers }\end{array}$ & 4 & 13.3 & 6 & 20 & 2 & 6.7 & 9 & 30 & 9 & 30 & 30 & 100 \\
\hline $\begin{array}{l}\text { Education policies in school are tight on } \\
\text { teachers thus they get dissatisfy with their job }\end{array}$ & 2 & 6.7 & 7 & 23.3 & 3 & 10 & 7 & 23.3 & 11 & 36.7 & 30 & 100 \\
\hline $\begin{array}{l}\text { Teaching and learning resources are in } \\
\text { adequate thus De-motivate agricultural } \\
\text { teachers }\end{array}$ & 11 & 36.7 & 9 & 30 & 2 & 6.7 & 5 & 16.7 & 3 & 10 & 30 & 100 \\
\hline $\begin{array}{l}\text { There are rules and regulation in school which } \\
\text { De-motivate agricultural teachers }\end{array}$ & 10 & 33.3 & 7 & 23.3 & 3 & 10 & 5 & 16.7 & 5 & 16.7 & 30 & 100 \\
\hline
\end{tabular}

\section{CONCLUSION}

This study has been able to establish the important factors affecting agricultural teachers' motivation to work diligently. Even though some are not satisfied with working conditions and salaries, they are still willing to continue teaching agricultural science, and expose their students to the practical aspect of agricultural production, which will invariably affect these students in the nearest future when they eventually focus on agriculture as their source of livelihood.

\section{CONFLICT OF INTEREST}

There is no conflict of interest in this study which intercepts with other studies or third party.

\section{REFERENCES}

(1) Van den Bosch F, Jeger MJ, Gilligan CA. Disease control and its selection for damaging plant virus strains in vegetatively propagated staple food crops; a theoretical assessment. Proceedings of the Royal Society B: Biological Sciences. 2007 Jan 7; 274 (1606):11-8.
(2) Asim M. Impact of Motivation on Employee Performance with effect of training: Specific to Education Sector of Pakistan. International Journal of Scientific and Research Publications. 2013 Sep; $3(9): 1-9$.

(3) Chen Y, Zheng C. Global asymptotic stability of a delayed plant disease model. Mathematics in Applied Sciences and Engineering. 2020 Feb 24; 1(1):27-38.

(4) Hargrove MB. Hargrove, MB, Nelson, DL, and Cooper, CL (2013) Generating eustress by challenging employees: Helping people savor their work. Organizational Dynamics. 42, 61-69. Organizational Dynamics. 2013; 42:61-9.

(5) Qureshi MA, Hamid K. Impact of supervisor support on job satisfaction: A moderating role of fairness perception. International Journal of Academic Research in Business and Social Sciences. 2017; 7(3):235-42.

(6) ur Rehman M, Irum R, Tahir N, Ijaz Z, Noor U, Salma U. The impact of job stress on employee job satisfaction: A study on private colleges of Pakistan. Journal of Business Studies Quarterly. 2012 Mar 1; $3(3): 50$.

(7) Mahmood, A. Azhar M, Nudrat S, Asdaque MM, Nawaz A, Haider N. Job satisfaction of secondary school teachers: A comparative analysis of gender, 
urban and rural schools. Asian Social Science. 2011 Aug; 7(8):203-6.

(8) Mamatha C, Prasad KD. Employee Performance A Function of Social Support And Coping: A Case Study with Reference to Agricultural Research Sector Employees Using Multinomial Logistic Regression. IOSR Journal of Business and Management. 2017; 19 (7):21.

(9) Safiullah AB. Impact of rewards on employee motivation of the telecommunication industry of Bangladesh: An empirical study. Journal of Business and Management. 2014; 16(12):22-30.

(10) Danish RQ, Usman A. Impact of reward and recognition on job satisfaction and motivation: An empirical study from Pakistan. International journal of business and management. 2010 Feb 1; 5(2):159.

(11) McKim AJ, Sorensen TJ, Velez JJ, Henderson TM. Analyzing the Relationship between Four Teacher Competence Areas and Commitment to Teaching. Journal of Agricultural Education. 2017; 58(4):1-4.

(12) Abu-Shamaa R, Al-Rabayah WA, Khasawneh RT. The effect of job satisfaction and work engagement on organizational commitment. IUP Journal of Organizational Behavior. 2015 Oct 1;14(4).

(13) Mupanemunda M. Councils as employers of choice: how hiring and procurement decisions can create employment for people with disability. Brotherhood of St Laurence, Fitzroy, Vic. 2020; 1-20.

(14) Travis N, Valadez JRN and Michelle CN. The Reaction of $\mathrm{Cp}^{*}(\mathrm{Cl}) \mathrm{M}($ Diene $)(\mathrm{M}=\mathrm{Ti}$, Hf $)$ with
Isonitriles. I Am Chem Soc. 2015; 137(32), 1015210155.

(15) Giang NS, Nguyen MT. An Investigation of the Impact of Interior Design on Job Performance: A Study on Hospitality Employees in Vietnam. International Journal of Social Science and Humanity. 2017 Jun 1; 7(6):386.

(16) Dmadwiandr. (2013). Journal of Chemical Information and Modeling, 53(9), 1689-1699. https://doi.org/10.1017/CB09781107415324.004

(17) Bakr AF, El Sayad ZT, Thomas SM. Virtual reality as a tool for children's participation in kindergarten design process. Alexandria engineering journal. 2018 Dec 1; 57(4):3851-61.

(18) Acquisti A, Taylor C, Wagman L. The economics of privacy. Journal of economic Literature. 2016; 54(2):442-92.

(19) Onyemuche, E.Managing Human Resources for the Achievement of Quality Secondary Education in Rivers State. International Journal of Innovative Development \& Policy Studies. 2018; 6(2): 20-26.

(20) Asuquo AI. Factors that influence accounting as career choice of Nigerian University students in the 21st century. The Certified National Accountant. 2011:34-8.

(21) Adamu B. Effective School Plants Maintenance: Issues and Approaches in Nigerian Schools. KIU Journal of Social Sciences. 2019 May 5; 5(1):199-203. 